UNITED STATES DEPARTMENT OF THE INTERIOR

J. A. Krug, Secretary

GEOLOGICAL SURVEY

W. E. Wrather, Director

\title{
Bulletin 940
}

\section{STRATEGIC MINERALS INVESTIGATIONS, 1943}

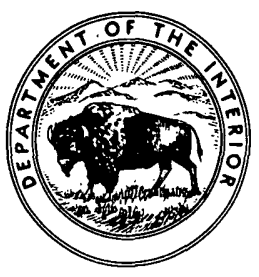

UNITED STATES

GOVERNMENT PRINTING OFFICE

WASHINGTON : 1944

For sale by the Superintendent of Documents, U. S. Government Printing Office, Washington 25, D. C. Price 5 cents 


$$
\begin{aligned}
& \text { QUE } 75 \\
& \text { BS } \\
& \text { no. } 940 \\
& \text { CopY } 2
\end{aligned}
$$


[The letters in parentheses preceding the titles are those used to designnate the papers for separate publication]

Page

(A) The Rose Creek Tungsten Mine, Pershing County, Nev,,

by R. J. Roberts (published in June 1943)........

Manganese Deposits of the Elkton area, Va., by P. B. King (publish ed in November 1943)..........

(C) Geophysical Surveys in the Ochoco Quicksilver district, Oreg., by E. I. Stephenson (published

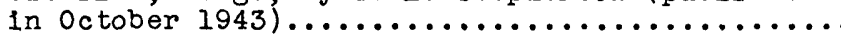

(D) Vanadium-bearing magnetite-ilmenite deposits, near Lake Sanford, Essex County, N. Y., by J. R. Balsley, Jr. (published in January 1944)........

(E) Occurrence of manganese in eastern Aroostook County, Malne, by W. S. White (published in December

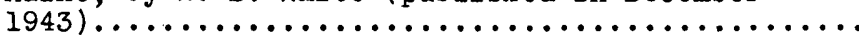

(F) Manganese deposits of the Lyndhurst-Vesuvius district, Auguste and Rockbridge Counties, Va., by M. M. Knechtel (published in January 1944)....

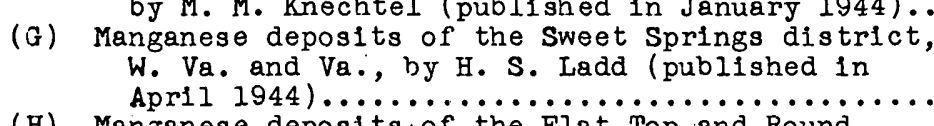

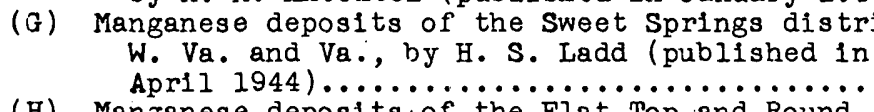

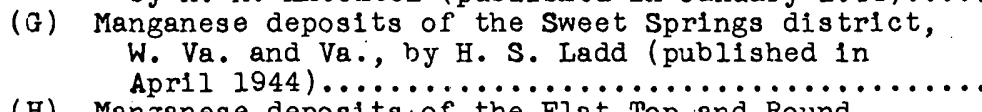
Mountain districts, Bland and Giles Counties, Va., by H. S. Ladd and F. W. Stead (published In September 1944). W. Stoad (publishod 1n

(I) Tungsten deposits in the Boriana district and the Aquarlus Range, Mohave County, Arlz., by S.W.

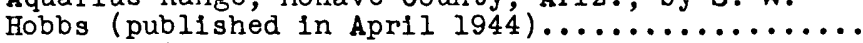

(J) Cobalt-bearing manganese deposits of Alabama, Georgia, and Tennessee, by W. G. Plerce (published in october $1944 \ldots \ldots \ldots \ldots \ldots \ldots \ldots \ldots \ldots \ldots \ldots . . \ldots \ldots$

265

\section{ILLUSTRATIONS}

Page

Piate 1. Preliminary geologic map and section of the Rose. Creek area, Persing County,

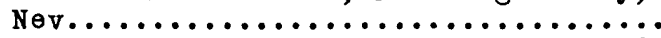

2. Preliminary geologic map and section of the Rose Creek mine and vicinity, Pershing County, Nev............... In pocket

3. Geologic map and section of the Rose Creek mine, workings............. In pocket

A. Geologic map and sections of the Elkton area, Virginia............. In pocket 
Plate 5. Map of the stanley mine and its surround-

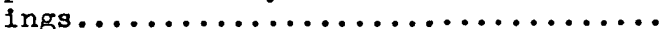

6. Map of the Watson tract and its surround-

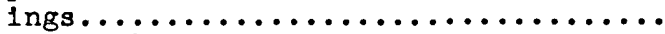

7. Geological profile of incline on Watson

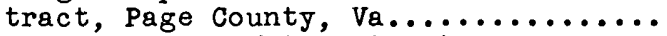

8. Sections across Watson tract...........

9. Map of the Elkton mines and their surroundings...................

10. Plan map of a part of the Johnson Creek area showing magnetometer grid........

11. Magnetic map of a part of the Johnson

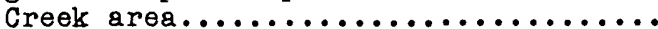

12. Detalled magnetic map of the area surrounding the Blue Ridge shaft, Johnson Creek area.................

13. Topographic map of the Taylor Ranch mine showing magnetometer traverses...

14. Magnetic map of the Taylor Ranch mine...

15. Magnetic map of Grid 1, Taylor Ranch

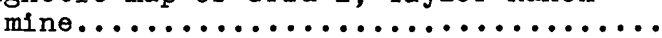

16. Horizontal resistivity profiles at the

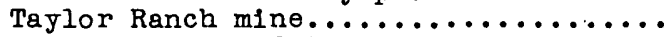

17. Topographic map of the Maury Mountain mine showing magnetometer traverses and plan of mine workings............

18. Magnetic map of a part of the Maury

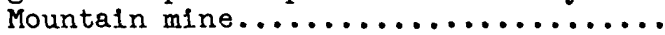

19. Geologic and topographic map of Sanford Hili magnetite deposit, Essex County,

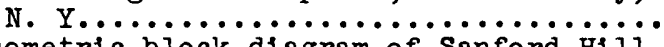

20. Isometric block diagram of Sanford Hili mine........................

21. Geologic and topozraphic map of Iron Mountain magnetite deposit, Essex County, N. Y.....................

22. Geologic and topographic map of Calamity Mil1 Pond magnetite deposit, Essex

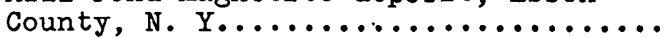

23. Geologic and topographic map of Cheney Pond magnetite deposit, Essex County,

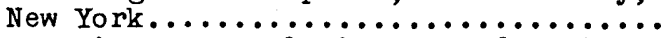

24. Reconnalssance geologic map and sections of the Presque Isle area, Aroostook County, Maine....................

25. Geologic map of manganiferous hematitic shale locality in southeast Castle Hill townsh1p....................

26. Distribtuion of manganiferous hematitic shale in the southern half of the Houlton quadrangle, Maine.............

27. Outcrop map of an area on the south side of Westford Hill..................

28. Geologic map of Westford Hili area, Hodgdon, Maine..................

29. Geologic map and sections of the Lyndhurst-Vesuvius district, Augusta and Rockbridge Counties, Va...........

30. Map of Mt. Torry tract, Augusta County, Va...........................

In pocket In pocket

In pocket 68

In pocket 84 In pocket

In pocket

In pocket

In pocket

In pocket

In pocket

In pocket

In pocket

128

132

140

140

160

In pocket

In pocket 
Plate 31. Map of Kennedy mine, Augusta County,

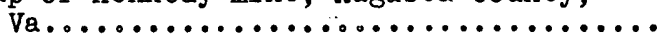

32. Map of Mine Bank workings, Augusta

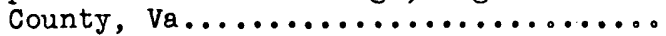

33. Map of Vesuvius mine, Augusta County,

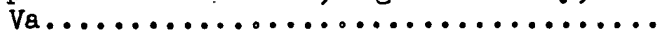

34. Plans and section of workings of the Vesuvious mine, Vesuvius, Va..........

35. Geologic map and sect1on, Sweet Springs

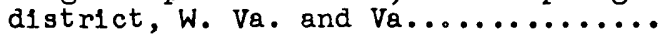

36. Map and section of Gap Mountain properties, Sweet Springs, W. Va.........

37. Geologic map and section of Flat Top

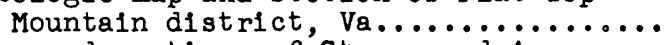

38. Map and sections of Stange and Arms

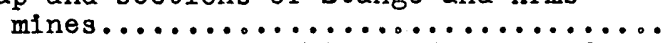

39. General plan of workings, stange and

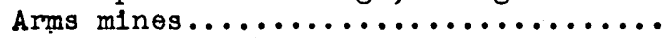

40. Geologic map and sections of Round

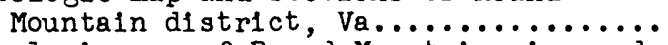

41. Geologic map of Round Mountain mine and

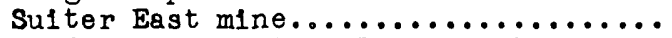

42. Map of mining claims, Borlana mine,

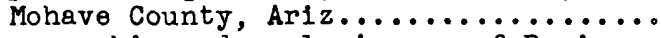

43. Topographic and geologic map of Borlana mine, Mohave County, Ariz............

44. Plan and sections of underground work-

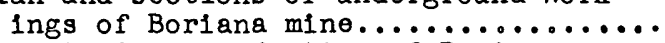

45. Longitudinal projection of Boriana

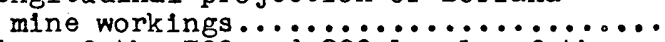

46. Plan of the 700 and 800 leveis of the Boriana mine, showing distribution

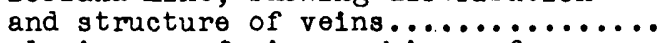

47. Geologic map of mine work ings of

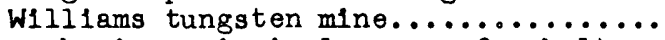

In pocket

In pocket

In pocket

In pocket

In pocket

In pocket

In pocket

In pocket

In pocket

In pocket

254

In pocket

262

48. Map showing princlpal areas of cobaltbearing manganese oxide and the rock formations with which they are

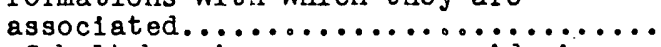

49. A, Cobalt-bearing manganese oxide in brecclated Welsner quartzlte; $\underline{B}$, Cobalt-bearing manganese oxide in the

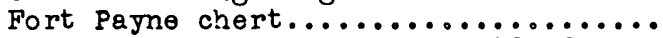

50. A, Cobalt-bearing manganese oxide from the Gemes mine near Cartersvilie, Ga.; $B$, View of pellet-bearing clay overIying manganiferous chert of the knox

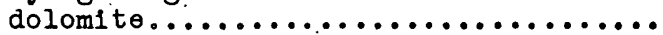

51. Map of the Gemes mine, Cartersvilie

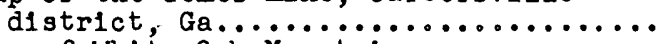

52. Map of White Oak Mountain manganese area, Bradley County, Tenn........... 
Plate 53. Geologic map of the Rock Run area, Ala..

Page

54. Cobaltiferous manganese prospects in the Rock Run area, Cherokee County,

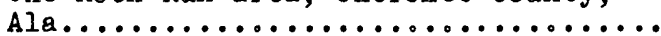

55. Maps of the Cedartown, Ga., manganiferous

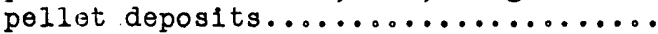

Figure 1. Index map of Nevada, showing location of the Rose Creek mine................

2. Index map of Virginia, showing location

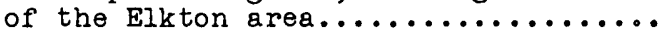

3. Sketch of cut on Norfolk \& Western Railroad, showing relations of residual clay.

4. Section of Stanley mine, showing relations of anclent gravel deposits......

5. View of Grindstone Mountain and Watson

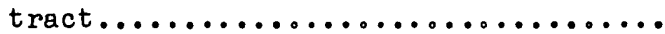

6. Index map of Oregon showing the Ochoco quicksilver district and the Round

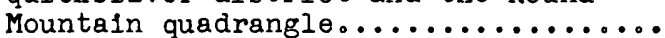

7. Diagrammatic sketch of an inferred fault system in a part of the Johnson Creek

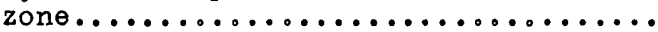

8. Horizontal resistivity profiles near the

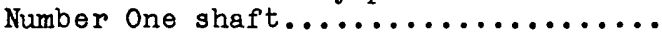

9. Index map of part of northeastern New York state showing location of the Lake Sanford district...............

10. Schematic diagram of mineral composition of rocks in the Lake Sanford district.

11. Diagram showing calculated mineral composition of ore samples in table $3 . .$.

12. Diagram showing chemical composition of the magnetic concentrates of ore samples in table $3 \ldots \ldots \ldots \ldots \ldots . . . .$.

13. Index map showing location of ore deposits in the Lake Sanford district.

14. Index map of Main showing location of Presque Isle and Houlton areas........

15. Index map of Virginia, showing location of Lyndhurst-Vesuvius district........

16. Map of Lyndhurst mine and vicinity,

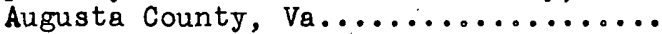

17. Map and cross sections of main open pit of Mine Bank mine, Augusta County, Va.

18. Sketches of Hogpen Hollow prospect,

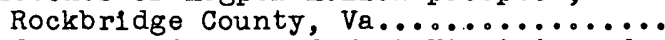

19. Index map of part of West Virginis and Virginia showing location of the sweet

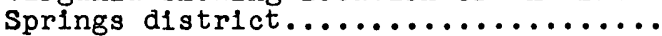

20. Fence diagram showing distribution of main ore zones on Baker tract, Gap Mountain......................... 
Page

Figure 21. Index map showing location of Flat Top Mountain and Round Mountain districts,

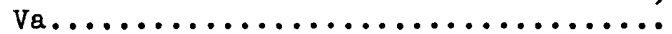

22. Manganese oxides and red clay along. bedding planes and joint cracks in Becraft sandstone at Arms mine.......

23. Manganese oxides in Becraft sandstone

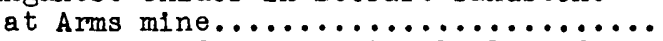

24. Manganese oxldes in residual clay of Tonoloway limestone in the Hall pit of the Round Mountain mine............

25. Fence diagram showing geologic relations at Round Mountain mine..........

26. Fence diagram showing distribution of ore at Round Mountain mine...........

27. Index map of Arizona showing location of the Boriana and Aquarlus Range tungsten deposits.................

28. Map of the Williams tungsten mine area, Mohave County, Arlz...............

TABLES

Table 1. Geological formations of the Elkton

2. Manganese and iron mines and prospects

Page

3. Chemical analyses and calculated minerai composition of samples of vanadiumbearing magnetite rock from Lake

Sanford district, Essex County, N. Y..

4. Estimated reserves in Lake Sanford

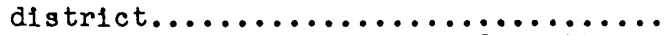

5. Estimated reserves at larger deposits to a depth of 10 feet...............

6. Partial analyses of surface samples of manganiferous rocks of Aroostook

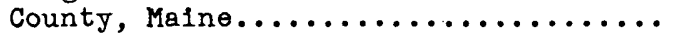


UNITED STATES DEPARTMENT .OF .. THE INTERIOR

Harold L. Ickes, Secretary.

GEOLOGICAL SURVEY

W. E. Wrather, Director

\title{
Bulletin 940-A
}

\section{THE ROSE CREEK TUNGSTEN MINE PERSHING COUNTY, NEVADA}

\author{
BY \\ RALPH J. ROBERTS
}

Strategic Minerals Investigations, 1943

(Pageg 1-14)

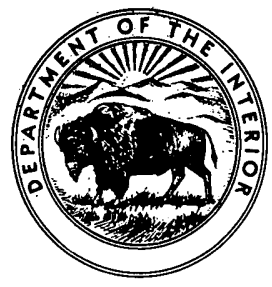

UNITED STATES

GOVERNMENT PRINTING OFFICE

WASHINGTON : 1943

For sale by the Superintendent of Documents, U. S. Government Printing Office, Washington. D. C. 



\section{CONTENTS}

\section{Page}

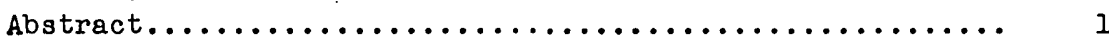

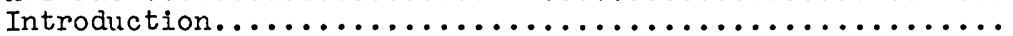

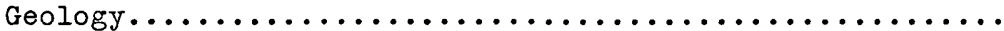

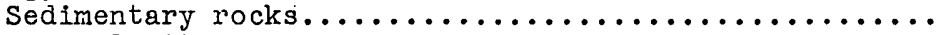

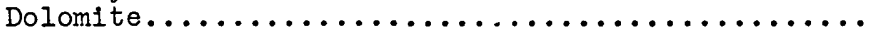

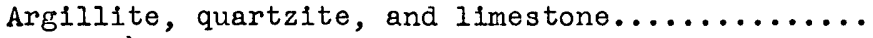

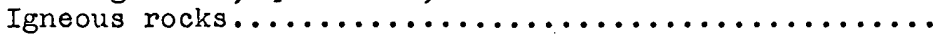

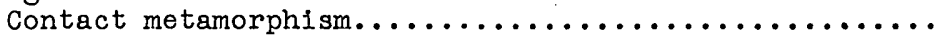

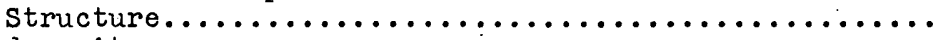

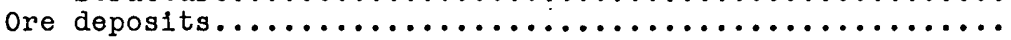

Mineralogy ...............................

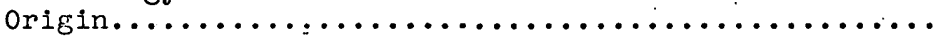

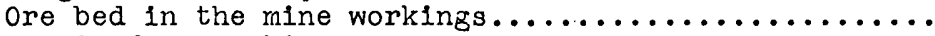

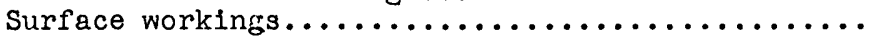

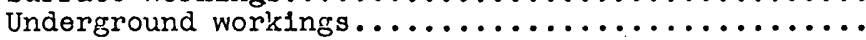

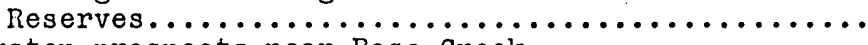

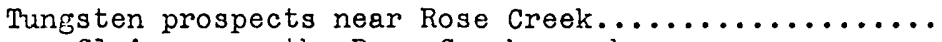

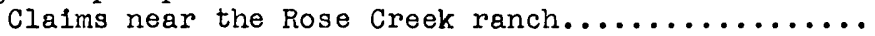

occurrences south of the Rose Creek mine..........

\section{ILLUSTRATIONS}

Plate 1. Preliminary geologic map and section of the Rose Creek area, Pershing County, Nev..... In pocket 2. Preliminary geologic map and section of the Rose Creek mine and vicinity, Pershing County, Nev..................... In pocket 3. Geologic map and section of the Rose Creek mine workings.................... In pocket

Figure 1. Index map of Nevada, showing location of the

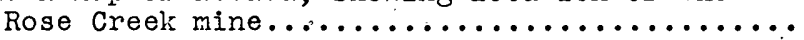





\title{
THE ROSE CREEK TUNGSTEN MINE,
}

\section{PERSHING COUNTY, NEVADA}

\author{
By Ralph J. Roberts
}

ABSTRACT

The Rose Creek tungsten mine is in the north end of the East Range, 11 miles southwest of Winnemucca, Nev. No tungsten ore has been produced from the property, but if high prices continue to prevail the mine will probably be brought into production.

The rocks in the area are interbedded argillite, quartzite, and Iimestone of Triassic age, which have been folded into northwest- and north-trending folds and overthmist by dolomite. These rocks have been intruded by granite, granodiorite, and many dikes, and have been complexly faulted. Near intrusive contacts the sedimentary rocks have been metamorphosed to hornfels and tactite. The scheelite deposits occur in the tactite and in quartz veins that cut the other rocks.

The tactite bed in the Rose creek mine has been explored in the workings for 400 feet along the strike and 200 feet down dip. It is as much as 4 feet thick but averages about 2 feet throughout the workings.

The ore reserves are estimated to be about 6,000 tons containing about 1.5 percent $\mathrm{WO}_{3}$. If only the thicker and richer portions of the bed are mined, the amount would be about 4,000 tons of 1.7-percent ore. Losses in mining may reduce these tonnages by about 10 percent, but the reserves may be increased by finding ore east and west of the present workings and in depth.

Scheelite was also found in quartz veins and in granite in the canyon south of the Rose Creek mine and in tactite near the Rose Creek ranch, but these occurrences have not been explored. Thorough exploration of the surface in the area by ultraviolet light may reveal the presence of other ore bodies.

\section{INTRODUCTION}

The Rose Creek mine, in sec. 6, T. 34 N., R. 37 E., is in the northeastern part of the East Range and 11 miles southwest of Winnemucca, Nev. (fig. 1). The nearest shipping point is Rose Creek, a station 3 miles north of the mine, on the Southern Pacific Railroad and U. S. Highway No. 40. Dirt roads that will 


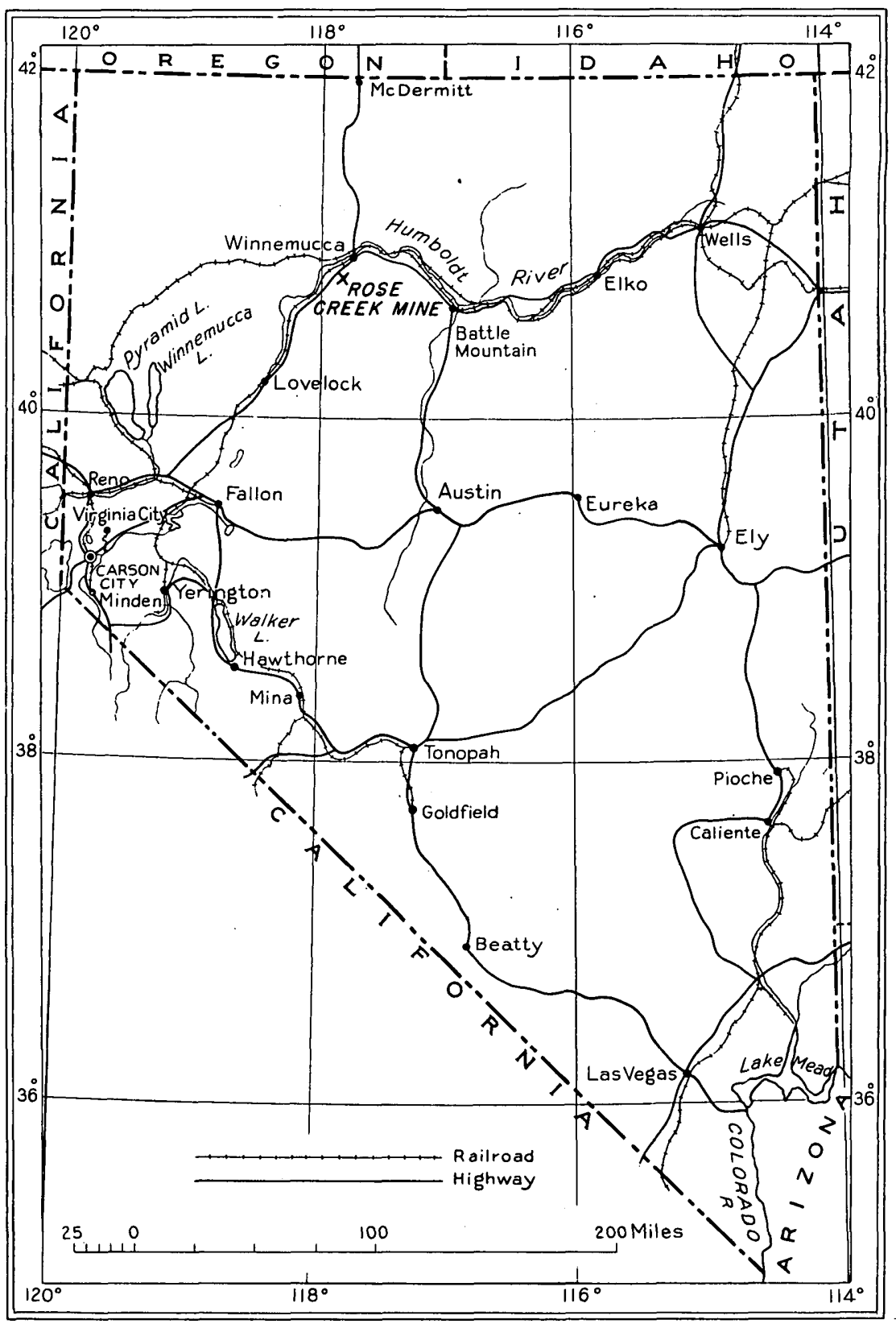

Figure 1.--Index map of Nevada showing location of the Rose Creek mine. permit heavy hauling except during the winter months lead from Rose Creek station to the mine. 
There has been intermittent mining activity in the northern part of the East Range since the 1860's. The Sierra district, 7 miles south of Rose Creek, has yielded ore containing gold, silver, copper, and lead. Quartz veins in the two canyons south of Rose Creek and near the Rose Creek mine probably attracted attention in the early days of mining, but were never worked. The Rose Creek mine was first located for copper and gold, but no exploratory work was done until 1936, when tungsten was discovered by Ed Christierson and George Howe. The property was sold to the United States Vanadium Corporation in December 1937, and considerable development work has been done since then. In 1942 the property was leased to Mr. W. C. Rigg. Ore from the Rose Creek mine will be treated in a mill at the Getcliell mine in the Osgood Range, 20 miles northeast of Winnemucca.

Field work in the Rose Creek area was begun by the Geological Survey in 1939, under the direction of H. G. Ferguson, as part of the areal mapping of the Sonoma Range quadrangle, and was continued intermittently during the field seasons of 1940 and 1941. The mine area (pl. 2) and underground workings were mapped by the writer with the assistance of A. E. Granger and Manning W. Cox. H. G. Ferguson and S. W. Muller mapped part of the area shown on plate $l$ and gave valuable advice during the field work. Clarence Hall, engineer for the United States Vanadium Corporation, aided field work in many ways and kindly gave permission to publish the assays of the ore.

T. B. Nolan and Ward Smith visited the party in the field and made valuable suggestions in the preparation of the manuscript. The writer is also indebted to F. C. Calkins for critical reading of the manuscript.

\section{GEOLOGY}

The East Range is a rugged northward-trending range in the central part of the Great Basin. The northern part of the range 
at the Rose Creek mine is about 6 miles wide; it rises abiuptly from alluvial fan slopes at an altitude of about 4,700 feet, and Lang Syne Peak, its highest point. in this a rea, is 7,430 feet above sea level.

This part of the range is composed of complexly folded and faulted Triassic sedimentary rocks, which have been intruded by small bodies of 1 gneous rock. The sedimentary rocks are dolomite, limestone, argillite, and quartzite. The igneous rocks include stocks of granite, diorite, and granodiorite and dikes of diorite porphyry, lamprophyre, and diabase. Near the intrusive bodies the argillite has been metamorphosed to hornfels and tactite, and the dolomite, limestone, and quartzite have been recrystallized. The scheelite occurs in the tactite and in quartz veins that cut the other rocks.

\section{Sedimentary rocks}

The sedimentary rocks comprise two units. Dolomite, probably the oldest rock exposed in the area, forms an overthrust sheet; interbedded argillite, quartzite, and limestone form the plate below the thrust. Interbedded limestone members near the bottom and top of this unit are shown separately on the map, plate 1. These rocks are probably all of Triassic age, but since they have not yielded diagnostic fossils their precise age is not known.

Dolonite.-The dolomite is exposed in several klippenl/ south and southeast of the mine; the largest of these is a mile long and 2,500 feet wide. Most of the klippen are downfaulted by normal faults and have thus been preserved from erosion. The dolonite has a maximum thickness of about 200 feet; it is massive to thick-bedded, and its colors range from light to dark gray. In most places it is silicified and cut by networks of

I/ A klippe is an outlier of an overthrust plate or sheet. 
small quartz veins. No fossils have been found in this dolomite, but similar massive dolomite that occurs in other parts of the Sonoma quadrangle contains Triassic fossils.

Argilite, quartzite, and limestone.--The sedimentary rocks below the thrust fault are chiefly argillite, quartzite, and limestone. Their thickness was not accurately measured but may be as much as 3,000 feet. Argillite predominates in the lower part, but near the Rose Creek Ranch several impure limestone beds are intercalated with the argillite. The middle part is composed of interbedded brown quartzite, argillite, and black slaty argillite. The argillite has been altered to hornfels over much of the area mapped. Some of the beds that were originally calcareous argillite, such as the tactite ore bed in the Roṣe Creek mine, have been entirely recrystallized near the intrusives and are now largely composed of silicates. The upper part of the lower plate is composed of interbedded limestone and slate. The Iimestone has been mapped separately on plate 1 . It is thin- to medium-bedded and contains thin layers of shaly limestone; for the most part it is light to dark gray in color, but it has been bleached white in some places along faults. According to s. W. Muller, $2 /$ fossils collected from the limestone indicate that its age is probably upper Triassic。

\section{Igneous rocks}

The intrusive igneous rocks shown on plates 1 and 2 are stocklike bodies, which commonly cut across the bedding. They are composed mainly of granite, granodiorite, and diorite. Many varieties of dike rocks, which cut the granitic and sedimentary rocks, are found in the area.

The intrusive bodies east and southeast of the Rose Creek mine consist of granite with a narrow granodiorite border. The

2/ Muller, S. W., personal communication.

525178 O- $43-2$ 
granite is medium-grained and contains pink orthoclase crystals. The bordering granodiorite is generally only a few feet wide; it is fine- to medium-grained and dark gray in color. A system of joints striking $\mathrm{N} \cdot 10^{\circ}-20^{\circ} \mathrm{W}$. and dipping steeply southwest is well developed in these intrusives. Many of the joints contain thin veins of quartz and of quartz and feldspar.

The intrusive body southwest of the Rose Creek mine is composed chiefly of granodiorite and diorite. It ranges from fineto medium-grained in texture, and from light gray to dark gray in color.

The dike rocks are of many different lithologic types. Granite and granodiorite dikes cut the metamorphic rocks adjacent to the intrusives. Small pegmatite and aplite dikes from a fraction of an inch to a foot wide, follow joints in the stocks, and some of them extend a short distance into the sedimentary rocks.

Basic dikes, chlefly of lamprophyre, diorite porphyry, and diabase, are numerous throughout the area, but they do not crop out prominently and only a few of them were mapped.

In the mine workings (pl. 3) dikes of lamprophyre and diabase have broken and displaced the ore bed. The lamprophyres fill irregular fractures which have no uniform strike and dip. Locally the lamprophyres contain scheelite near their contacts with the ore bed, so that they evidently were intruded before the close of tungsten metallization. Most of the diabase dikes, on the other hand, were intruded after the tungsten metallization. They trend north and northeast and dip steeply.

The age of the intrusive rocks is not definitely known. They cut Triassic rocks and are therefore Triassic or younger. The diabase dikes were intmuded later than the other 1gneous rocks, since they cut the granite and the other dikes. In 
nearby areas similar diabase dikes are found to be feeders of basalt flows that are probably Tertiary. $3 /$

\section{Contact metamorphism}

The metamorphic effects of the granite and granodiorite intrusions are noticeable in most of the area shown on plate 2 , though contact metamorphism was naturally more intense at the borders of the intrusive masses. Commonly the wall rocks are feldspathized for a few feet from the contacts, and they are recrystallized as much as a mile away from the contacts.

Limestone and quartzite beds were least affected; though they became coarser-grained, their mineral composition was changed only slightly. In places tremolite needles were formed in the limestone, and the color of the limestone was changed from gray to white.

The argillite has been altered to hornfels over a wide area. The hornfels is a gray, green, or brown rock, composed chiefly of quartz, mica, epidote, and actinolite; most of it is minutely fractured.

Calcareous argillite beds, such as the ore bed in the Rose Creek mine, were entirely changed to tactite for hundreds of feet away from the contact. The tactite consists largely of diopside, actinolite, epidote, quartz, feldspar, and calcite in varying proportions. Small quantities of scheelite and sulfides are present in some places.

\section{Structure}

The rocks of the Rose Creek area are complexly folded and. faulted. In many places the structural details have not been

3/ Roberts, R. J., Quicksilver deposits of the Bottle Creek district, Humboldt County, Nev.: U. S. Geol. Survey Bull. 922-A, p. 7, 1940. 
worked out because of poor exposures, and the contacts in such places are generalized.

The dips in the area northeast of the Valley fault suggest that the structure there is anticlinal. The principal structural feature southwest of the Valley and Peak faults is a syncline pitching southeastward. The granodiorite appears to have been emplaced along the axis of this syncline.

The overthrust fault at the base of the dolomite strikes east and dips gently to the north. The actual thrust plane is not exposed, but its location is fairly certain in most places. The rocks near the thrust plane, both above and below, are fractured and brecciated. The direction of thrusting appears to have been to the southwest or west. Overthrusts in the Sonoma Range, 7 miles to the east, also appear to have moved westward. The overthrust fault has been broken by many normal faults, and because of subsequent erosion small klippen have been isolated west and south of the largest klippe.

The normal faults may be divided into two systems, a younger system striking northwest, and an older system striking north to northeast. The amount of displacement along them ranges from a few feet to several hundred feet, but on most of the faults no accurate measure of the throw is obtainable. The downthrown block is commonly on the southwest side of the faults that strike northwestward, and may be on either side of those that strike northward. None of the small faults that displace the ore layer in the workings has a throw greater than 10 feet. Some of the diabase and lamprophyre dikes follow faults.

\section{ORE DEPOSITS}

The scheelite-bearing tactite bed explored in the Rose Creek mine workings $(\mathrm{pl} .3)$ is the only ore body of comercial size and grade thus far discovered in the area. The bed is similar 
in occurrence and general mineralogy to the scheelite-bearing. beds mined in the Nevada-Massachusetts mine 4 / in the Eurrene Range, 17 miles to the southwest.

Claims have been located on tactite near the granodiorite contact at the Rose Creek ranch. The granite and the veins of quartz and of quartz and feldspar in the canyon east of Rose Creek contain scattered scheelite crystals, but further explóration will be needed to prove whether they contain ore bodies of cornmercial size.

\section{Mineralogy}

The tactite, formed by alteration of calcareous argillite, is composed chiefly of diopside, actịnolite, feldspar, quartz, calcite, epidote, and zoisite; the relative abundance of these minerals is variable, but diopside, actinolite, feldspar, and quartz commonly predominate. The rock also contains minor quantities of apatite, sphene, scheelite, pyrite, nolybdenite, sphalerite, arsenopyrite, and chalcopyrite. The sulfides occur in small quartz veins and are disseminated throughout the tactite and in the adjacent rock. Pyrite, the most abundant sulfide, is widespread, and chalcopyrite is common; the others are present only locally.

The scheelite forms subhedral to euhedral grains and is commonly disseminated through the tactite, but locally the grains are distributed along cracks or occur in small quartz veinlets. The scheelite ranges in size from crystals too small to be seen with the unalded eye to crystals half an inch in length.

The fluorescence color under the ultraviolet lamp indicates that there are two varieties of scheelite in the ore: one that fluoresces bluish white and another that fluoresces light

4/ Kerr, P. F., Tungsten deposits near Mill City, Nev.: Univ. of Nevada Bull., vol. 28 , No. 2, pp. 21-30, 1934 . 
yellow. Some crystals consist entirely of the white variety, others of the yellow, but more commonly both varieties occur together, irregularly intergrown in the same crystal. Some crystals have a central core of one variety surrounded by a shell of the other; the yellow variety forms the core more commonly. than the white. The yellow color is due to a small quantity of molybdenum in the scheelite. Comparison of the fluorescence colors of the two varieties with samples of known molybdenum content5/ indicates that the white variety contains about 0.05 percent molybdenum and the yellow variety about 1.8 percent. It is impossible to estimate the molybdenum content of the yellow and white intergrowths, but concentrates of the ore are said to contain about 1.5 percent of molybdenurn.

The ore is reported to contain as much as 1.5 percent copper and 0.14 ounce gold a ton.

\section{$\underline{\text { Origin }}$}

The tungsten deposits in the Rose Creek area were formed by hydrothermal solutions, probably related in origin to the granitic rocks. The scheelite was formed by reaction between the tungsten-bearing solutions and calcareous beds near intrusive contacts and was localized in and near fractures.

\section{Ore bed in the rine workings}

The ore bed in the Rose Creek mine workings lies parallel in general to the bedding of the enclosing argillite, but it thins and swells along the strike and down dip. In most places it strikes eastward and dips $30^{\circ}-45^{\circ}$ northward, but locally the strike is northeast and there are many minor flexures.

The ore body has been developed for a length of 400 feet and for a distance of 200 feet down dip (a vertical distance of 110 
feet). In the underground workings, it is as much as 4 feet thick but averages about 2 feet. It contains as much as 5 percent $\mathrm{WO}_{3}$, but a verages about 1.5 percent. In the surface workings its average thickness appears to be about $2 \frac{2}{2}$ feet and the average grade about 1 percent $\mathrm{WO}_{3}$.

Surface workings.--The ore bed was first explored in shallow surface workings (see pl. 3), which extend for 500 feet al ong Its strike, and its average thickness in these workings is about $2 \frac{1}{2}$ feet. It pinches out completely in raise No. 1 , which connects with the underground workings, but elsewhere its outcrop is from 1 to 9 feet wide. The sample cuts in the trenches were made across the contours of the hill, but since the bed dips gently into the hill the length of the sample cuts is somewhat greater than the true thickness of the bed.

The surface ore is oxidized; the sulfides have been altered to limonitic iron oxides and the silicates to clay minerals. The altered rock is commonly stained with copper carbonates and silicates and is porous. The depth of oxidation is shallow, ranging from 3 to about 10 feet, and is greatest where the rock is fractured.

Three lamprophyre dikes were noted in surface cuts, but float indicates that there are many others between the cuts.

A parallel ore bed, whose outcrop width is 10 feet, was cut In the long trench at the southwestern end of the surface workings. Its grade is low, but further exploration of it appears to be warranted.

Underground workings.--The underground workings consist of an adit-drift which follows the ore bed for 400 feet, an inclined winze following the ore down the dip, three raises, and a crosscut. In october 1941, an adit was being driven at a lower level to intersect the winze.

The ore bed is exposed at the portal of the upper level and in a pit northeast of the portal. In the pit the bed ends 
against a fault. The bed east of the pit will probably run into a diabase dike and continue beyond it, but the contact is not exposed; and no extension northeast of the dike has yet been found.

The ore bed was cut 30 feet from the portal, in the roof of the adit. Beyond this point it is broken by several faults of small displacement and was not followed by the drift. It was encountered again in the crosscut at the head of the inclined winze.

The bed is split into two parts, separated by barren rock, where first encountered in the West drift. This condition apparently is due tó an original irregularity in the bedding of the calcareous argillite from which the bed was formed. In raise No. I the ore bed becomes thin, and pinches out completely near the surface. It also thins between raise No. 2 and raise No. 3 , and is cut out by faults and two dikes at the 4-foot winze. Where the ore bed is found again at the south crosscut it is 30 inches thick; here it was followed upward in a short raise, but it was found to be cut off by a lamprophyre dike 10 feet above the drift. It is also cut off by a diabase dike west of the crosscut. Ore was found in the northwest drift, but it is of low grade. Ore probably continues beyond the diabase dike in the face, but its position on the other side of the dike is not known.

The inclined winze follows the ore down dip for 170 feet. In the upper part the ore is of high grade, assaying as high as 5.07 percent $\mathrm{WO}_{3}$, but between the lamprophyre and the diabase dike it is thinner and mostly lean. The layer below the diabase dike has not been assayed, but it also appears to be low grade. At a distance of 170 feet down dip below the top of the winze the ore, which is there only 6 inches thick, is cut off by a fault. The bed may continue below this level, but short drill holes into the roof and floor did not encounter 1 t. 
The lower adit is in dike rock and argillite to the face. The ore layer, if it extends to this level, may be cut before the adit intersects the bottom of the winze, or it may be necessary to run a crosscut to the south in the block between the lower adit and the winze. The faults which displace the ore bed on the upper adit level near the winze crosscut will probably cause a similar displacement in the bed on the lower adit level.

Reserves.--Although little ore can be considered to be blocked out in the workings, enough exploration has been done to allow fairly accurate estimation of the reserves in the mine. The ore bed has been proved to be continuous throughout the workings except where it is cut out by dikes. On the drift level dikes occupy about 30 percent of the distance from the portal to the face, and in the winze they occupy about 20 percent of the distance through which the ore extends. On the surface, because of poor exposures between trenches, the relative percentage of dikes and argillite cannot be estimated, but. it is probably of about the same order here as in the underground workings.

By assuming 2 feet as the average thickness of the ore body, and subtracting 30 percent for the volume of dike rock, the amount of ore in the block between the portal and present face is estimated to be about 6,000 tons. Assays indicate that the average grade will be about 1.5 percent $\mathrm{WO}_{3}$.

In actual mining, however, it may be found that only the richer and thicker parts of the ore bed can be extracted profitably. If 18 inches is assumed to be the minimum stoping thickness, the reserves may be about 4,000 tons. If the material containing less than $I$ percent $\mathrm{WO}_{3}$ is left in the ground, the average content of the ore mined will be about 1.7 percent $\mathrm{WO}_{3}$.

The tonnage may be further reduced because of faulted blocks, and segrnents of the bed isolated by dikes, that cannot be profitably mined. It is difficult to, estimate these losses 
in advance of mining, but they may reduce the tonnage by 10 percent or more.

The reserves may be increased considerably by finding ore east and west of the present workings and at depth. Other scheelite-bearing beds may be discovered near the workings; surface trenching and prospecting by ultraviolet light is desirable.

\section{Tungsten prospects near Rose Creek}

Scheelite-bearing veins of quartz and of quartz and feldspar were noted at three other localities in the Rose Creek area (see pl. 1). These occurrences have not been explored, and 1 is not known whether they include any ore bodies of commercial size and grade.

Claims near the Rose Creek ranch.--Claims have been located in sec. 2, T. 34 N., R. $36 \mathrm{E}$, , on tactite exposed in the stream bed east of the Rose Creek ranch (No. I in pl. 1). A few crystals of scheelite were seen in the rock, but no material that appears to be of commercial value has yet been found.

Occurrences of the Rose Creek mine.--In the canyon south of the Rose Creek mine two occurrences of scheelite were found by prospecting with the ultraviolet lamp. No. 2 (see pl. 1) is in granite near the granite-limestone contact; No. 3 is in quartz and quartz-feldspar veins which cut the granite on the west wall of the canyon.

The quartz and quartz-feldspar veins that contain scheelite range in width from a fraction of an inch to more than 6 inches but do not average more than 2 inches. The veins are 4 inches to 2 feet apart and follow a joint system. In the granite that strikes $\mathrm{N} .10^{\circ}-20^{\circ} \mathrm{W}$. In the veins examined, scheelite crystals are erratically distributed through the quartz, and the veins do not appear to be of commercial grade. In places the granite adjacent to the velns contains sparse scheollte crystals. 